\title{
Interactions between Ephrin-B and Metabotropic Glutamate 1 Receptors in Brain Tissue and Cultured Neurons
}

\author{
L. Calò, ${ }^{1}$ V. Bruno, ${ }^{1,2}$ P. Spinsanti, ${ }^{1}$ G. Molinari, ${ }^{2}$ V. Korkhov, ${ }^{3}$ Z. Esposito, ${ }^{1}$ M. Patanè, ${ }^{1}$ D. Melchiorri, ${ }^{1}$ M. Freissmuth, ${ }^{3}$ \\ and F. Nicoletti ${ }^{1,2}$ \\ ${ }^{1}$ Department of Human Physiology and Pharmacology, University of Rome "La Sapienza," 00185 Rome, Italy, ${ }^{2}$ Istituto Neurologico Mediterraneo \\ Neuromed, 86077 Pozzilli, Italy, and 'Institute of Pharmacology, University of Vienna Medical School, A-1090 Vienna, Austria
}

We examined the interaction between ephrins and metabotropic glutamate (mGlu) receptors in the developing brain and cultured neurons. EphrinB2 coimmunoprecipitated with mGlula receptors, in all of the brain regions examined, and with mGlu5 receptors in the corpus striatum. In striatal slices, activation of ephrinB2 by a clustered form of its target receptor, EphB1, amplified the mGlu receptormediated stimulation of polyphosphoinositide (PI) hydrolysis. This effect was abolished in slices treated with mGlu1 or NMDA receptor antagonists but was not affected by pharmacological blockade of mGlu 5 receptors. An interaction among ephrinB2, mGlu1 receptor, and NMDA was supported by the following observations: (1) the NR1 subunit of NMDA receptors coimmunoprecipitated with mGlu1a receptors and ephrinB2 in striatal lysates; (2) clustered EphB1 amplified excitatory amino acid-stimulated PI hydrolysis in cultured granule cells grown under conditions that favored the expression of mGlula receptors; and (3) clustered EphB1 amplified the enhancing effect of mGlu receptor agonists on NMDA toxicity in cortical cultures, and its action was sensitive to mGlu1 receptor antagonists. Finally, fluorescence resonance energy transfer and coclustering analysis in human embryonic kidney 293 cells excluded a physical interaction between ephrinB2 and mGlula (or mGlu5 receptors). A functional interaction between ephrinB and mGlu1 receptors, which likely involves adaptor or scaffolding proteins, might have an important role in the regulation of developmental plasticity.

Key words: mGlu receptors; ephrinB; postnatal development; polyphosphoinositide hydrolysis; cerebellar granule cells; NMDA toxicity

\section{Introduction}

The evidence that ephrin (Eph) receptors associate and interact with NMDA receptors at synaptic sites (see below) provides an example of how molecules that are classically involved in developmental pattering and cell-cell communication (Kullander and Klein, 2002) may regulate excitatory neurotransmission and synaptic plasticity. Eph receptors and their ligand ephrins are subdivided into two classes named $\mathrm{A}$ and $\mathrm{B}$. With few exceptions, Aand B-subclass ephrins bind to EphA and EphB, respectively, thus generating a bidirectional signaling (Holland et al., 1996; Kullander and Klein, 2002; Himanen et al., 2004). Although Ephs constitute the largest family of tyrosine kinase receptors, ephrin ligands signal through the engagement of adaptor or scaffolding molecules. The cytoplasmic tail of ephrinB is phosphorylated when the EphB receptor is presented by neighboring cells or as soluble fusion protein (Bruckner et al., 1997; Parker et al., 2004), thereby recruiting proteins containing Src homology 2 ( $\mathrm{SH} 2) / \mathrm{SH} 3$ or postsynaptic density-95/Discs large/zona occludens-1 (PDZ)

\footnotetext{
Received June 21, 2004; revised Jan. 10, 2005; accepted Jan. 10, 2005.

M.F. was supported by grants from the European Community ("Epileptosome") and the Austrian Science Foundation. V.K. is supported by a Bertha-von-Suttner stipend from the Austria Academic Exchange Service. We thank Dr. D. Wilkinson for providing the mouse ephrinB2 CDNA. We also thank Dr. Laurent Fagni for the constructs encoding tagged versions of mGlu1 and mGlu5.

Correspondence should be addressed to Dr. Ferdinando Nicoletti, Department of Human Physiology and Pharmacology, University of Rome "La Sapienza," Piazzale Aldo Moro 5, 00185 Rome, Italy. E-mail: ferdinandonicoletti@hotmail.com.

DOI:10.1523/JNEUROSCI.4956-04.2005

Copyright $\odot 2005$ Society for Neuroscience $\quad$ 0270-6474/05/252245-10\$15.00/0
}

domains (Torres et al., 1998; Bruckner et al., 1999; Cowan and Henkemeyer, 2001; Palmer et al., 2002). Dalva et al. (2000) first showed a direct association between the N-terminal domains of EphB2 and the NMDA receptor 1 (NR1) subunit of NMDA receptors. This interaction is promoted by the presence of ephrinB acting in "trans" (i.e., either exogenously added or present on a different cell). In cultured cortical neurons, activation of EphB by ephrinB2 potentiates NMDA receptor-dependent function, suggesting a mechanism whereby activity-dependent and -independent signals converge in the regulation of synaptic plasticity (Takasu et al., 2002). Although in the above studies EphB receptors are shown to act postsynaptically and ephrinBs presynaptically, Grunwald et al. (2004) have recently shown that the Eph/ephrin system is used in an inverted manner in the hippocampus, where postsynaptic ephrinB2 and NMDA receptors interact in the induction of long-term forms of synaptic plasticity.

Group I metabotropic glutamate receptors (mGlul and mGlu5 receptors) interact with NMDA receptors and are involved in the regulation of developmental plasticity. Expression of these receptors is developmentally regulated (Nicoletti et al., 1986a; Schoepp and Johnson, 1989; Minakami et al., 1995; Romano et al., 1996; Casabona et al., 1997) and is temporally related to critical times of experience-dependent synaptic modifications (Dudek and Bear, 1989). Group I mGlu receptors are crosslinked with NMDA receptors through a chain of anchoring proteins (Tu et al., 1999), and their activation amplifies NMDA cur- 
rents (Aniksztejn et al., 1995; Awad et al., 2000; Pisani et al., 2001; Skeberdis et al., 2001; Heidinger et al., 2002; Kotecha and MacDonald, 2003). In addition, activation of mGlu1 receptors accelerates NMDA receptor trafficking (Lan et al., 2001), and the NMDA component of long-term potentiation is abolished in mice lacking mGlu5 receptors (Jia et al., 1998). The interaction between group I mGlu receptors and NMDA receptors is reciprocal, because NMDA receptor activation potentiates mGlu5 receptor responses by reversing mGlu5 receptor desensitization (Alagarsamy et al., 1999). This prompted us to examine the interaction(s) between ephrins and group I mGlu receptors in the developing brain.

\section{Materials and Methods}

Materials. A recombinant rat EphB1/Fc chimera containing the extracellular domain of rat EphB1 receptor (amino acid residues 1-538) or a recombinant human EphA1/Fc chimera containing the extracellular domain of human EphA1 receptor (amino acid residues 1-547) fused to the C-terminal 6X histidine-tagged Fc region of human IgG via a polypeptide linker was purchased from R \& D Systems (Milan, Italy). When required, the EphB1 or the EphA1 chimera was clustered by a $40 \mathrm{~min}$ incubation at $37^{\circ} \mathrm{C}$ in buffer containing an AffiniPure goat anti-human IgG, $\mathrm{Fc}_{\gamma^{-}}$ specific $(1: 2.5 \mathrm{w} / \mathrm{w})$ (Jackson ImmunoResearch, Milan, Italy). L-Quisqualic acid, L-glutamic acid, (RS)-3,5-dihydroxyphenylglycine (DHPG), 2-methyl-6-(phenylthynyl)pyridine hydrochloride (MPEP), (S)-(+)- $\alpha$-amino-4-carboxy-2-methylbenzeneacetic acid (LY367385), 7-(hydroxyimino)cyclopropa[b]chromen-1a-carboxylate ethyl ester (CPCCOEt), 2,3-dioxo-6-nitro-1,2,3,4-tetrahydrobenzo[f] quinoxaline7 -sulfonamide (NBQX), and dizocilpine (MK-801) were purchased from Tocris Cookson (Bristol, UK); all other drugs or chemicals were purchased from Sigma-Aldrich (Milan, Italy).

Immunoprecipitation and Western blot analysis. Sprague Dawley rats (Charles River, Calco, Italy) at postnatal day 6-7 (P6-7), C57/N6 mice (Charles River), or mGlu5 knock-out mice (The Jackson Laboratory, Bar Harbor, ME) (Battaglia et al., 2001) at P6 were killed by decapitation. The indicated brain regions were removed, and tissue was extracted in $\mathrm{HO}$ buffer (50 mм HEPES-NaOH, pH 7.5, 1\% Triton X-100, 0.15 м NaCl, 1 mM EGTA, $1.5 \mathrm{~mm} \mathrm{MgCl}_{2}, 10 \%$ glycerol) containing $1 \mathrm{~mm}$ benzamidine, $1 \mathrm{~mm}$ PMSF, $50 \mathrm{~mm} \mathrm{NaF}, 2.8 \mu \mathrm{g} / \mathrm{ml}$ aprotinin, and $1 \mathrm{~mm} \mathrm{Na}_{3} \mathrm{VO}_{4}$, as described by Buchert et al. (1999). One milligram of lysate was incubated with $5 \mu \mathrm{g}$ of immunoprecipitating antibody (see below) and bound to protein A-Sepharose beads (Sigma-Aldrich). For Western blot analysis, proteins were resuspended in SDS-bromophenol blue buffer containing $20 \mathrm{~mm}$ dithiothreitol, separated on 8\% SDS-PAGE [for mGlu1, mGlu5, mGlu2/3, NR1, and regulator of G-protein signaling 3 (RGS3)] or $12 \%$ SDS-PAGE (ephrinB2 and Homer), transferred to nitrocellulose membranes, immunoblotted, and revealed by ECL (Amersham Biosciences, Milan, Italy). The following antibodies were used: rabbit polyclonal antimGlula and mGlu5 receptors (1:1000; Upstate Biotechnology, Milan, Italy); rabbit polyclonal anti-mGlu2/3 receptors (1:1000; Chemicon, Temecula, CA); rabbit polyclonal anti-NR1 (splice variant isoforms A, B, C, and F; $1 \mu \mathrm{g} / \mathrm{ml}$; Upstate Biotechnology); rabbit polyclonal anti-ephrinB2 (1:300); goat polyclonal anti-Homer (1:500) (both from Santa Cruz Biotechnology, Milan, Italy); rabbit polyclonal RGS3 (1:500; Torrey Pines Biolabs, San Diego, CA); and rabbit polyclonal anti-ephrinAl (Santa Cruz Biotechnology).

Immunocytochemistry. Mixed cortical cultures at $13 \mathrm{~d}$ in vitro (DIV) and confluent astrocytic cultures (10 DIV), prepared as described above, were fixed with $2 \%$ paraformaldehyde/ $10 \mathrm{~mm}$ PBS for $10 \mathrm{~min}$. Cultures were then incubated overnight at $4^{\circ} \mathrm{C}$ with polyclonal rabbit antibody anti-mGlu1 (1:100; Upstate Biotechnology), polyclonal rabbit antibody anti-ephrinB2 (1:200; Santa Cruz Biotechnology), or monoclonal mouse antibody anti-GFAP (1:400; Sigma), followed by a $1 \mathrm{~h}$ incubation with the secondary biotin-coupled anti-rabbit or anti-mouse antibodies (1: 200; Vector Laboratories, Burlingame, CA). Cells were rinsed extensively in PBS and then incubated for $1 \mathrm{~h}$ with the ABC Elite reagent (Vector Laboratories). Color development was achieved by incubating the cells in 3,3'-diaminobenzidine tetrachloride (Vector Laboratories) for the de- tection of mGlu1 and ephrinB2 and in Vector Novared substrate (Vector Laboratories) for the detection of GFAP. Photographs were taken at $20 \times$ using an inverted microscope.

Measurement of polyphosphoinositide hydrolysis in brain slices. Slices $(350 \times 350 \mu \mathrm{m})$ were prepared from the corpus striatum or cerebral cortex of P6-7 rats, as described previously (Nicoletti et al., 1986a), and incubated at $37^{\circ} \mathrm{C}$ under constant oxygenation for $45 \mathrm{~min}$ in KrebsHenseleit buffer, $\mathrm{pH}$ 7.4. Forty microliters of gravity packed slices were transferred to vials containing $1 \mu \mathrm{Ci}$ of myo[2- $\left.{ }^{3} \mathrm{H}\right]$ inositol (specific activity, $10 \mathrm{Ci} / \mathrm{mmol}$; Amersham Biosciences) to label inositol phospholipids. At the end of this incubation, $10 \mathrm{~mm} \mathrm{LiCl}$ was added, followed 10 min later by mGlu receptor agonists or carbamylcholine. When present, mGlu receptor antagonists and/or EphB1/Fc were added 5-10 min before receptor agonists. The incubation was continued for $60 \mathrm{~min}$ and then terminated by the addition of methanol:chloroform:water (1:1:1). The amount of $\left[{ }^{3} \mathrm{H}\right]$ inositolmonophosphate (InsP) accumulated during the reaction was measured as described previously (Nicoletti et al., 1986a).

Measurement of agonist-stimulated polyphosphoinositide hydrolysis in cultured cerebellar granule cells. Primary cultures of cerebellar granule cells were prepared from 8-d-old rats, as described previously (Nicoletti et al., 1986b), and grown onto $35 \mathrm{~mm}$ Nunc Petri dishes in basal Eagle's medium (Invitrogen, Milan, Italy) containing 10\% fetal calf serum, $2 \mathrm{~mm}$ glutamine, $0.05 \mathrm{mg} / \mathrm{ml}$ gentamycin, and $25 \mathrm{~mm}$ (K25) or $10 \mathrm{~mm}$ (K10) $\mathrm{K}^{+}$(added as $\left.\mathrm{KCl}\right)$. Cytosine arabinofuranoside $(10 \mu \mathrm{M})$ was added $16-18 \mathrm{~h}$ after plating to avoid the replication of non-neuronal cells. Cultures grown in K10 medium were used after 4 DIV, whereas cultures grown in K25 medium were used at 9 DIV. Western blot analysis of mGlula receptor, mGlu5 receptor, or ephrinB2 was performed as described above. For the stimulation of polyphosphoinositide (PI) hydrolysis, cultures were incubated overnight with myo $\left[2-{ }^{3} \mathrm{H}\right]$ inositol $(2 \mu \mathrm{Ci} /$ dish), washed in Krebs-Henseleit buffer containing $10 \mathrm{~mm} \mathrm{LiCl}$, and incubated for $30 \mathrm{~min}$ at $37^{\circ} \mathrm{C}$ under constant oxygenation. Receptor agonists were added, and the incubation was continued for $30 \mathrm{~min}$. Clustered EphB1/Fc or MK-801 was added 5 min before receptor agonists. $\left[{ }^{3} \mathrm{H}\right]$ InsP formation was measured as described above.

Preparation of mixed cultures of mouse cortical cells and assessment of excitotoxic neuronal death. Cortical cultures containing both neurons and astrocytes were prepared from fetal mice at $14-16 \mathrm{~d}$ of gestation, as described previously (Rose et al., 1992). Briefly, dissociated cortical cells were plated onto $15 \mathrm{~mm}$ multiwell vessels (Falcon Primaria, Lincoln Park, NJ) on a layer of confluent astrocytes with minimum essential medium (MEM)-Eagle's salts supplemented with $5 \%$ heat-inactivated horse serum, $5 \%$ fetal bovine serum, glutamine $(2 \mathrm{~mm})$, and glucose $(21$ $\mathrm{mm})$. After 3-5 DIV, cultures were exposed to $10 \mu \mathrm{M}$ cytosine arabinofuranoside for $1-3 \mathrm{~d}$ and then shifted to a maintenance medium identical to the plating medium but lacking fetal bovine serum. Subsequent partial medium replacements were performed twice each week. Excitotoxicity experiments were performed at 13-14 DIV. For the induction of excitotoxic neuronal death, cultures were exposed for $10 \mathrm{~min}$ to submaximal concentrations $(30 \mu \mathrm{M})$ of NMDA at room temperature in a solution containing the following (in $\mathrm{mm}$ ): $120 \mathrm{NaCl}, 5.4 \mathrm{KCl}, 0.8 \mathrm{MgCl}_{2}, 1.8$ $\mathrm{CaCl}_{2}, 20 \mathrm{HEPES}$, and 15 glucose, $\mathrm{pH}$ 7.4. Afterward, cultures were washed extensively and incubated at $37^{\circ} \mathrm{C}$ for the following $24 \mathrm{~h}$ in MEM-Eagle's medium supplemented with $15.8 \mathrm{~mm} \mathrm{NaHCO}_{3}$ and $<25$ $\mathrm{mm}$ glucose. When present, quisqualate (in the presence of $10 \mu \mathrm{M}$ NBQX to avoid AMPA receptor activation), MPEP, CPCCOEt, LY367385, and EphB1/Fc were combined with NMDA during the 10 min pulse. Excitotoxic neuronal death was examined $20 \mathrm{~h}$ after the $10 \mathrm{~min}$ pulse by trypan blue staining. Stained neurons were counted from three random fields per well with phase-contrast microscopy at 100-400×.

Construction of fluorescently tagged ephrinB2, mGlu1a, and mGlu5 receptors. Mouse ephrinB2 cDNA (kindly provided by Dr. David Wilkinson, National Institute for Medical Research, London, UK) was cloned into pEYFP-N1 vector (Clontech, Heidelberg, Germany) by means of PCR. The following primers were used to generate an insert containing ephrinB2 flanked by HindIII and BamHI sites, respectively: $5^{\prime}$ ACGCAAGCTTATGGCCATGGCCCGGTCC-3' and 5'-CGGTGGATCCCCGACCTTGTAGTAAATGTTGGC-3'. Vector and insert were cut 
by these restriction enzymes (Roche, Vienna, Austria). Ligation was performed with the Fast-Link Ligation kit (Epicenter Technologies, Madison, WI). Sequence of the obtained construct was confirmed by sequencing. The plasmids encoding mGlu1 and mGlu5 receptors tagged with cyan fluorescent protein (CFP) on the $\mathrm{C}$ termini were kindly provided by Dr. Laurent Fagni (Centre CNRS-INSERM de PharmacologieEndocrinologie, Montpellier, France). Human dopamine $\mathrm{D}_{2}$ receptor was cloned into pECFP vector (Clontech), as described by Schmid et al. (2001). Preparation of the human serotonin transporter (hSERT) tagged with CFP and yellow fluorescent protein (YFP) (CFP-hSERT-YFP) has been described previously (Just et al., 2004).

Cell culture and transfections. Human embryonic kidney 293 (HEK293) cells were grown in DMEM containing L-alanyl-L-glutamine, $10 \%$ fetal bovine serum, and $50 \mathrm{mg} / \mathrm{L}$ gentamicin on $10 \mathrm{~cm}$ diameter cell culture dishes at $37^{\circ} \mathrm{C}$ in an atmosphere of $5 \% \mathrm{CO}_{2}, 95 \%$ air. One day before transfection, cells were replated to obtain subconfluent cultures either on poly-D-lysine-covered glass coverslips $(22 \mathrm{~mm}$ in diameter and placed into 6-well plates; $3 \times 10^{5}$ cells/well plate). Transient transfections were performed using the standard calcium phosphate precipitation method.

Fluorescence resonance energy transfer microscopy. Fluorescence microscopy was performed using a Zeiss (Thornwood, NY) Axiovert 200M inverted epifluorescence microscope equipped with a CoolSNAP fx cooled CCD camera (Photometrics; Roper Scientific, Tucson, AZ). The fluorescence filter sets were purchased from Chroma (Chroma Technology, Brattleboro, VT) [CFP filter set: excitation, $436 \mathrm{~nm}$; dichroic mirror, $455 \mathrm{~nm}$; emission, $480 \mathrm{~nm}$; YFP filter set: excitation, $500 \mathrm{~nm}$; dichroic mirror, $515 \mathrm{~nm}$; emission, $535 \mathrm{~nm}$; fluorescence resonance energy transfer (FRET) filter set: excitation, $436 \mathrm{~nm}$; dichroic mirror, $455 \mathrm{~nm}$; emission, $535 \mathrm{~nm}$ ]. Coverslips with attached cells were mounted in the microscope chamber and put on the microscope stage. Images of cells with CFP- and YFP-tagged proteins were acquired through corresponding filter channels. To measure donor recovery after acceptor photobleaching (DRAP), we acquired a donor (CFP) image before (Ib) and after (Ia) photobleaching using the YFP setting for $90 \mathrm{~s}$ (excitation, $500 \mathrm{~nm}$; dichroic mirror, $525 \mathrm{~nm}$; emission, $535 \mathrm{~nm}$ ). DRAP was quantified by FRET efficiency $(E)$ as described by Miyawaki and Tsien (2000) according to the following equation: $E=(\mathrm{Ia}-\mathrm{Ib}) / \mathrm{Ia}$.

\section{Results \\ Coimmunoprecipitation of ephrinB2 with group I mGlu receptors in brain tissue}

Expression of ephrinB2 was detected in the corpus striatum, cerebral cortex, hippocampus, and cerebellum of P6-7 rats (Fig. 1A). Lysates of brain tissue were immunoprecipitated with antiephrinB2 antibodies and then immunoblotted with mGlula, mGlu 5 , or $\mathrm{mGlu} 2 / 3$ receptor antibody. The mGlu 1 a receptor was detected in immunoprecipitates from all brain regions (Fig. $1 B$ ), whereas the mGlu5 receptor was mainly detected in immunoprecipitates from the corpus striatum (Fig. 1C). The mGlu5 receptor was also detected in ephrinB2 immunoprecipitates from the striatum of $\mathrm{P} 6$ wild-type mice but not in immunoprecipitates from mGlu5 knock-out mice (Fig. $1 D$ ). The $\mathrm{mGlu} 2 / 3$ receptor proteins were not detected in ephrinB2 immunoprecipitates (Fig. $1 F)$. Neither mGlula nor mGlu5 receptors were detected in immunoprecipitates of ephrinA1 (Fig. $1 G, H$ ). We also examined the coimmunoprecipitation among the NR1 subunit of NMDA receptors, the mGlu1 receptor, the mGlu5 receptor, and ephrinB2 in the developing rat striatum. We could detect the NR1 subunit in ephrinB2, mGlu1, and mGlu5 receptor immunoprecipitates (Fig. 1E). We extended the study to RGS3, which is known to interact with ephrinB2 through its PDZ domain (Su et al., 2004), and Homer proteins, which are the prototypical scaffolding proteins interacting with mGlula and mGlu5 receptors (Brakeman et al., 1997). In control brain tissue, RGS3 was detected as a band at $\sim 90 \mathrm{kDa}$, as expected. RGS3 could be detected
A

WB: ephrinB2

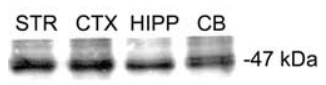

C IP: ephrinB2 WB: mGlu5

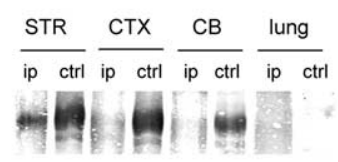

E

G

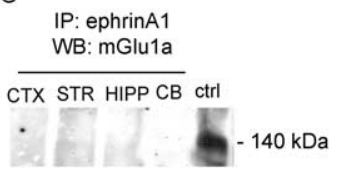

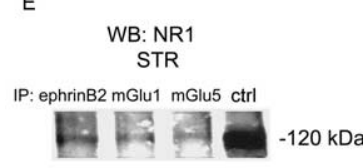

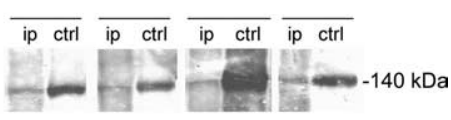

D
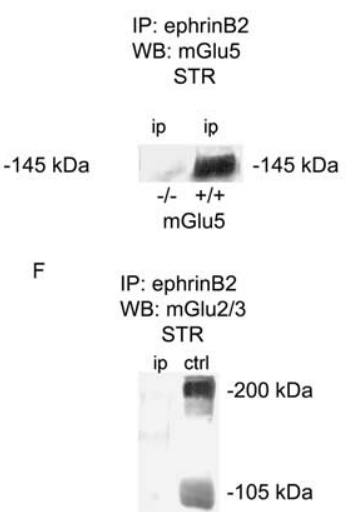

$\mathrm{H}$

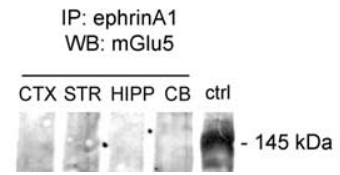

B IP:ephrinB2

CTX HIPP CB STR

Figure 1. EphrinB2 expression and coimmunoprecipitation with group I $\mathrm{mGlu}$ receptors and NR1 subunit of NMDA receptors in the postnatal brain. Western blot analysis of ephrinB2 in the corpus striatum (STR), cerebral cortex (CTX), hippocampus (HIPP), and cerebellum (CB) is shown in $\boldsymbol{A}$. $\boldsymbol{B}, \boldsymbol{C}$, Protein lysates of the CTX, HIPP, CB, and STR from P6-7 rats were immunoprecipitated (IP) with anti-ephrinB2 antibodies and then immunoblotted (WB) with anti-mGlu1a (B) or anti-mGlu5 ( $C$ antibodies. Controls (ctrl) represent nonimmunoprecipitated samples. C, Extracts from the adult rat lung are shown as a negative control. Coimmunoprecipitation of ephrinB2 and mGlu5 receptors in the striatum of wild-type and mGlu5 knock-out mice at P6 is shown in $\boldsymbol{D}$. $\boldsymbol{E}$, Lysates from the striatum of $\mathrm{P} 6-7$ rats were immunoprecipitated with antiephrinB2, anti-mGlu1a, or anti-mGlu5 antibody and immunoblotted with anti-NR1 antibodies; the lack of coimmunoprecipitation between ephrinB2 and $\mathrm{mGlu2/3}$ receptors in the striatum from $\mathrm{P} 6-7$ rats is shown in $\boldsymbol{F}$. $\mathbf{G}, \boldsymbol{H}$, Neither mGlu1a nor mGlu5 receptors are detected in ephrinA1 immunoprecipitates of the CTX, STR, HIPP, and CB from rats at P6-7. Nonimmunoprecipitated cerebellum $(\boldsymbol{G})$ and cerebral cortex $(\boldsymbol{H})$ are used as a control (ctrl).

in ephrinB2, mGlu1a, and mGlu5 receptor immunoprecipitates from the corpus striatum, cerebral cortex, and cerebellum (Fig. $2 A$ ). Homer proteins were detected using a pan-Homer polyclonal antibody. In control brain tissue, the antibody labeled two bands at $\sim 30$ and $43-45 \mathrm{kDa}$ corresponding to the molecular size of Homer-1a and Homer-1b/c, respectively, and additional bands of higher molecular size. The immunoreactive band corresponding to Homer-1b/c was detected in ephrinB2 immunoprecipitates from the cortex, hippocampus, striatum, and cerebellum of $\mathrm{P} 6-7$ rats (Fig. $2 \mathrm{~B}$ ).

\section{Functional interaction between ephrinB2 and group I mGlu receptors in brain slices}

We assessed the activity of group I mGlu receptors by measuring the stimulation of PI hydrolysis in slices prepared from the corpus striatum or the cerebral cortex of $\mathrm{P} 6-7$ rats. Of the three agonists classically used in this assay (i.e., $1 S, 3 R$-ACPD, quisqualate and DHPG), we excluded $1 S, 3 R-A C P D$, because stimulation of PI hydrolysis by this drug is partially mediated by the activation of mGlu2/3 receptors (Genazzani et al., 1994; Schoepp et al., 1996). In striatal slices, quisqualate induced a concentrationdependent stimulation of $\left[{ }^{3} \mathrm{H}\right] \mathrm{Ins} P$ formation, with an apparent 
A

WB: RGS3
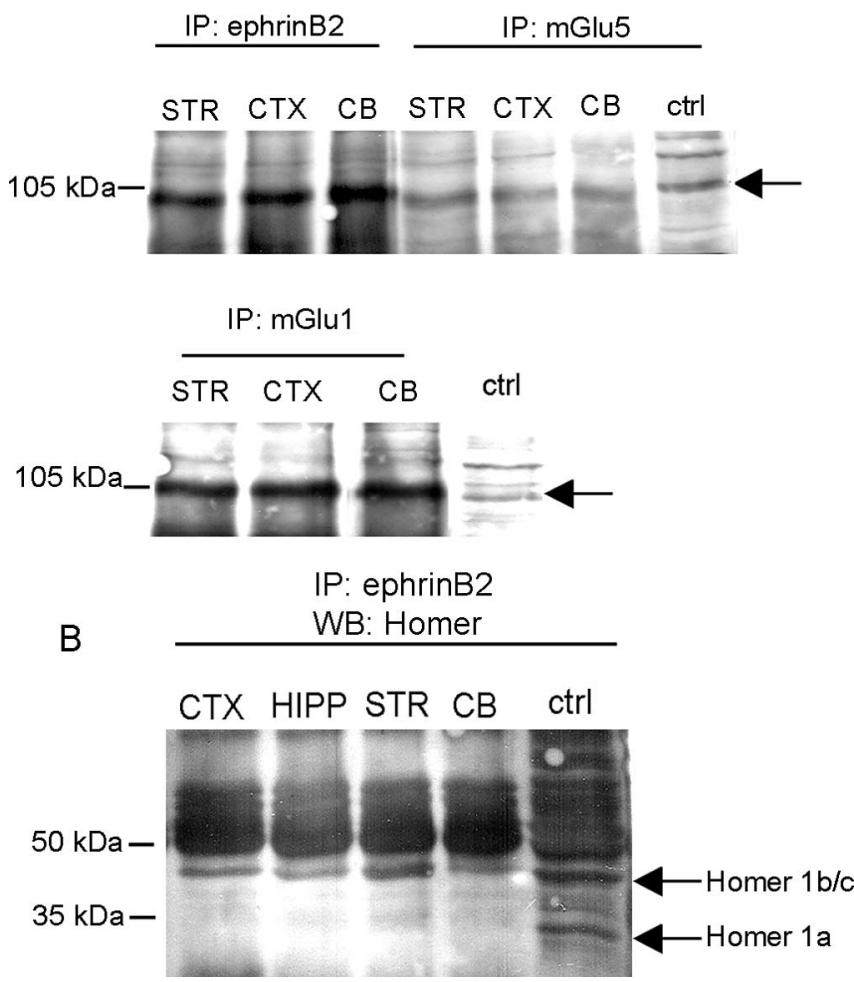

Figure 2. EphrinB2 coimmunoprecipitation with RGS3 and Homer in the postnatal brain. $A$, RGS3 is detected in ephrinB2, mGlu1a, and mGlu1a immunoprecipitates (IP) from P6 -7 rats. The detection of Homer proteins in ephrinB2 immunoprecipitates is shown in $\boldsymbol{B}$. All Homer proteins are simultaneously detected with a pan-Homer antibody. Note that the immunoreactive band corresponding to Homer $1 \mathrm{~b} / \mathrm{c}$ (but not that corresponding to Homer $1 \mathrm{a}$ ) is detected in all ephrinB2 immunoprecipitates. CB, Cerebellum; ctrl, control; CTX, cerebral cortex; HIPP, hippocampus; STR, corpus striatum.

$\mathrm{EC}_{50}$ value of $\sim 100 \mathrm{~nm}$ (Fig. $3 A$ ). Both mGlu1 and mGlu5 receptors contributed to this response, as shown by the inhibitory action of LY367385 (a competitive mGlu1 receptor antagonist) and MPEP (a noncompetitive mGlu5 receptor antagonist) (Fig. $3 B$ ). To activate ephrinB2, we incubated the slices with a chimeric $\mathrm{EphB} 1 / \mathrm{Fc}$ receptor clustered with an anti-Fc IgG. Clustered EphB1/Fc $(0.5 \mu \mathrm{g} / \mathrm{ml})$ added to striatal slices increased the potency of quisqualate in stimulating $\left[{ }^{3} \mathrm{H}\right] \mathrm{Ins}$ P formation without affecting the efficacy of the drug (Fig. 3A). Clustered EphB1/Fc failed to induce changes in the PI response to the muscarinic cholinergic receptor agonist charbamylcholine (Table 1). No potentiation of quisqualate-stimulated PI hydrolysis was observed after application of a nonclustered form of EphB1/Fc (Fig. 3A) or application of clustered EphA1/Fc $\left(0.5 \mu \mathrm{g} / \mathrm{ml} ;\left[{ }^{3} \mathrm{H}\right]\right.$ InsP formation expressed as $\mathrm{dpm} / \mathrm{mg}$ protein: basal, $2700 \pm 160$; clustered EphA1/Fc, $2440 \pm 85$; quisqualate, $300 \mathrm{~nm}, 5300 \pm 440$; quisqualate plus EphA1/Fc, $5050 \pm 115)$, an Eph member that does not bind to ephrinB2 (Pasquale, 2004). We examined the amplification of the PI response by clustered EphB1/Fc in the presence of a battery of glutamate receptor antagonists. Clustered EhpB1/Fc still potentiated the action of quisqualate in the presence of MPEP but became ineffective in slices treated with LY367385. The AMPA receptor antagonist, NBQX $(10 \mu \mathrm{M})$, had no effect on quisqualate-stimulated PI hydrolysis in both the absence and presence of clustered EphB1/Fc; in contrast, the NMDA receptor antagonist MK-801 $(1 \mu \mathrm{M})$ did not affect the ac-
A

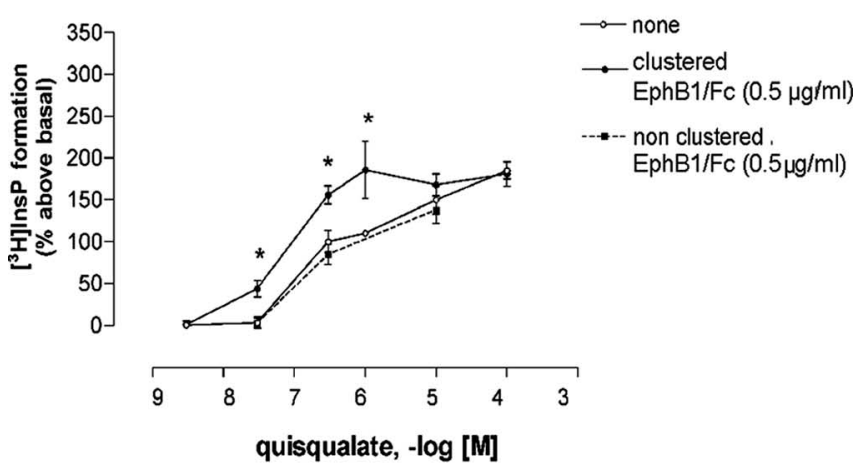

B

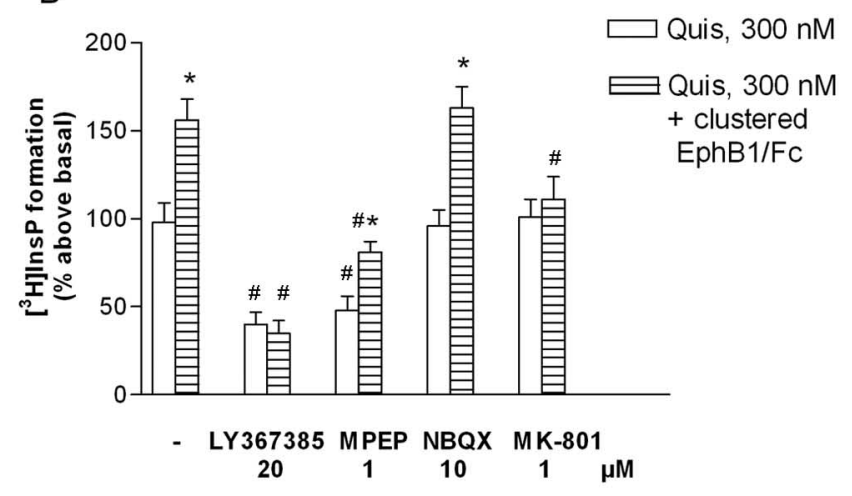

C

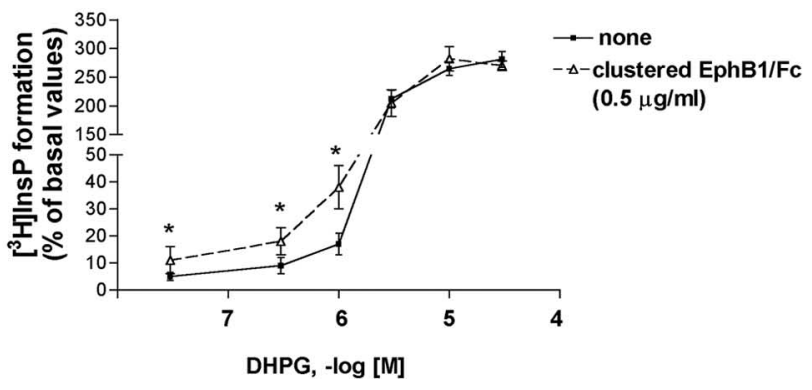

Figure 3. Activation of ephrinB by clustered EphB1/Fc amplifies the stimulation of PI hydrolysis by $\mathrm{mGlu}$ receptor agonists in striatal slices from $\mathrm{P} 6-7$ rats. A concentration-dependent stimulation of PI hydrolysis by quisqualate or DHPG in the absence or presence of clustered $E \mathrm{EhB} 1 / \mathrm{Fc}$ is shown in $\boldsymbol{A}$ and $\boldsymbol{C}$, respectively. Figure $2 B$ shows that the enhancing effect of clustered EphB/Fc is abrogated by the mGlu1 receptor antagonist LY367385 or by the NMDA receptor antagonist MK-801 but not by the mGlu5 receptor antagonist MPEP or the AMPA receptor antagonist NBQX. Values are means \pm SEM of $9-21(A)$ or $6-12(B, C)$ determinations; ${ }^{*} p<0.05$ (Student's $t$ test) compared with the respective values obtained in the absence of clustered EphB1/Fc; ${ }^{\#} p<0.05$ (one-way ANOVA plus Fisher's PLSD) compared with the respective values obtained with quisqualate or quisqualate plus clustered $\mathrm{EphB2} / \mathrm{Fc}$ without receptor antagonists.

tion of quisqualate alone but abolished the amplification of the PI response to quisqualate induced by clustered $\mathrm{EphB1/Fc} \mathrm{(Fig.} \mathrm{3B).}$ We extended the analysis to DHPG, which behaves as a selective mGlu1/5 receptor agonist (for review, see Schoepp et al., 1999). Similarly to that observed with quisqualate, addition of clustered EphB1/Fc to striatal slices also increased the potency of DHPG in stimulating PI hydrolysis (Fig. 3C). 
Table 1. EphB1/Fc selectively amplifies the $\mathrm{mGlu}$ receptor-mediated stimulation of PI hydrolysis in striatal slices

\begin{tabular}{lcc}
\hline & {$\left[{ }^{3} \mathrm{H}\right] \mathrm{lns} P(\mathrm{dpm} / \mathrm{mg}$ protein) } & \\
\cline { 2 - 3 } & Controls & Clustered EphB1/Fc $(0.5 \mu \mathrm{g} / \mathrm{ml})$ \\
\hline Basal & $3500 \pm 68$ & $3200 \pm 130$ \\
Quisqualate & & \\
$\quad 300 \mathrm{~nm}$ & $6800 \pm 320$ & $8500 \pm 240^{*}$ \\
CCh $100 \mu \mathrm{M}$ & $7100 \pm 140$ & $7050 \pm 450$ \\
CCh $1 \mathrm{mM}$ & $15,000 \pm 620$ & $14,500 \pm 850$ \\
\hline
\end{tabular}

Values are means \pm SEM of $9-12$ determinations. ${ }^{*} p<0.05$ (Student's $t$ test) versus the respective basal values.
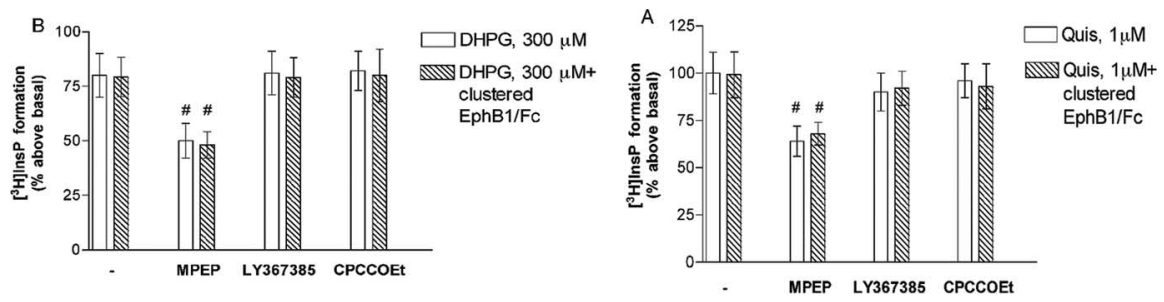

Figure 4. Clustered EphB1/Fc fails to amplify mGlu receptor-mediated PI hydrolysis in cortical slices from P6 -7 rats. Note that the PI response to quisqualate $(\boldsymbol{A})$ or DHPG $(\boldsymbol{B})$ was attenuated by MPEP but not by the mGlu1 receptor antagonists (PCCOEt and LY367385. Values are means \pm SEM of 12 determinations. ${ }^{\#} p<0.05$ (one-way ANOVA plus Fisher's PLSD) compared with the respective values obtained with quisqualate or quisqualate plus clustered $\mathrm{EphB2} / \mathrm{Fc}$ without receptor antagonists. the stimulation produced by low concentrations of quisqualate (100 nM). No potentiation was observed when cultures were stimulated by higher concentrations of quisqualate (1 or $100 \mu \mathrm{M})$. Clustered EphB1/Fc also amplified the PI response to $10 \mu \mathrm{M}$ glutamate but not to carbamylcholine $(10 \mu \mathrm{M})$ (Table 2). Knowing that a component of the PI response to glutamate in granule cells is mediated by the activation of NMDA receptors (Nicoletti et al., 1986b), we examined [ $\left.{ }^{3} \mathrm{H}\right]$ InsP formation in the presence of the NMDA receptor antagonist MK-801 (1 $\mu \mathrm{M})$. Clustered $\mathrm{EphB} 1 / \mathrm{Fc}$ failed to potentiate the PI response to glutamate in the presence of MK-801, indicating that activation of NMDA receptors is necessary for the modulation of mGlul receptors by ephrinB/EphB (Table 2). We also used young cultured granule cells (4 DIV) grown in 10 $\mathrm{mm} \mathrm{K}^{+}$(K10), which expressed mGlu5 receptors and very low levels of mGlu1 receptors (Fig. 5) (Copani et al., 1998). In these cultures, stimulation of PI hydrolysis by $1 \mu \mathrm{M}$ quisqualate was not affected by clustered EhpB1/Fc (Table 3), supporting the specificity of ephrinB/EhpB for cells expressing mGlul receptors.

Interaction between ephrin $\mathrm{B} 2$ and group I mGlu receptors in mixed cultures of cortical cells: study on NMDA toxicity

We extended the study of the interaction between ephrinB and group I mGlu receptors to mixed cultures of mouse cortical cells. These cultures are widely used for the study of excitotoxic neuronal death and carry the advantage of maintaining the physiological interplay between neurons and astrocytes. Using this model, we (and others) have shown that activation of either mGlu1 receptor or mGlu5 receptor amplifies NMDA toxicity (Bruno et al., 1995, 2000, 2001; Buisson and Choi, 1995; Battaglia et al., 2001). Western blot analysis confirmed the presence of mGlu1 and mGlu5 receptors in these cultures and also showed the expression of ephrinB2 (Fig. 6A). Immunohistochemistry showed that both mGlula receptors and ephrinB2 were expressed by neurons in mixed cortical cultures, whereas no expression was found in the underlying monolayer of astrocytes identified as $\mathrm{GFAP}^{+}$cells (Fig. 6B). This contrasts with the widespread expression of mGlu5 receptors, which were also found in astrocytes (data not shown). The lack of ephrinB2 and mGlula receptors in glial cells was confirmed using pure cultures of mouse cortical astrocytes (Fig. $6 \mathrm{~B}$ ). Mixed cultures were challenged with a 10 min pulse of $30 \mu \mathrm{M}$ NMDA for the induction of excitotoxic neuronal death. As expected, NMDA toxicity was amplified by the mGlu1/5 receptor agonist quisqualate $(100 \mathrm{nM}$ or 1 $\mu \mathrm{M})$ or DHPG $(3,30$, or $300 \mu \mathrm{M})$. Clustered EphB1/Fc $(0.5 \mu \mathrm{g} /$ $\mathrm{ml}$ ) applied during the toxic pulse further amplified the enhancing effect of quisqualate or DHPG on NMDA toxicity, producing only small effects on its own. In addition, quisqualate alone has no discernible effect on cell survival even when combined with clustered EphB1 (Fig. 6C,D; Table 4) (data not shown). Nonclustered EphB1/Fc was inactive (data not shown). To examine which group I mGlu receptor subtype was positively modulated by clustered EphB1/Fc, we treated the cultures with the mGlu5 receptor antagonist MPEP or with the mGlul receptor antagonists CPCCOEt or LY367385. These three antagonists were similarly effec-
Interaction between ephrinB2 and
cultured cerebellar granule cells

We examined the effect of clustered EphB1/Fc on group I mGlu receptor signaling in cultured cerebellar granule cells at 9 DIV grown in medium containing $25 \mathrm{~mm} \mathrm{~K}^{+}$(K25). These cultures expressed ephrinB2, high levels of mGlu1a receptors, and low levels of mGlu5 receptors (Fig. 5). The addition of clustered EphB1/Fc did not stimulate PI hydrolysis, per se, but enhanced 
tive in reducing NMDA toxicity both in the absence and in the presence of quisqualate or DHPG (Bruno et al., 2000). However, clustered EphB1/Fc could still amplify responses to quisqualate or DHPG when mGlu5 receptors were antagonized by MPEP $(3 \mu \mathrm{M})$ but became inactive when mGlul receptors were blocked by CPCCOEt $(10 \mu \mathrm{M})$ or LY367385 (1 $\mu \mathrm{M})$ (Table 4).

\section{FRET analysis of the interaction between group I mGlu receptors and ephrinB2 in transfected HEK293 cells} To address the question of whether mGlu1 and mGlu5 directly associate with ephrinB2, we used FRET microscopy on transiently transfected HEK293 cells. We fused ephrinB2 cDNA via its $\mathrm{C}$ terminus in frame with YFP. Plasmids encoding the obtained construct and mGlul-CFP and mGlu5-CFP were transiently coexpressed in HEK293 cells. We were unable to observe an increase in fluorescence of donor (CFP) after acceptor photobleaching in both cases (mGlu1-CFP plus ephrinB2YFP and mGlu5-CFP plus ephrinB2-YFP) (Fig. 7A), which is indicative of little or no direct interaction within the pairs of proteins. FRET relies on the distance between the fluorophores and their relative orientation. An interaction may escape detection if the two fluorophores are separated by a distance that is larger than the Foerster distance (50-100 $\AA$ in the case of YFP and CFP) and if their relative orientation is unfavorable (e.g., because of rational constraints). We therefore used an independent method to assess the interaction between mGlu1/5-CFP and ephrinB2-YFP chimeras. For that purpose, we coexpressed both proteins in HEK293 cells and applied the preclustered EphB1-Fc for $20 \mathrm{~min}$ at $37^{\circ} \mathrm{C}$. EphrinB2YFP was clustered into punctuate aggregates in cell membrane and internalized. However, both mGlu1-CFP and mGlu5-CFP did not redistribute together with ephrinB2, which would be expected provided the receptors directly associate with the latter. Similar experiments were also performed in the presence of 50 $\mu \mathrm{M}$ DHPG, which induced internalization of mGlu1 and mGlu5 receptors; the presence of the mGlu receptor agonist did not facilitate coclustering (Fig. $7 B$ ). This indicates once again that the interaction between mGlu1 or mGlu5 and ephrinB2 is unlikely to be direct.

\section{Discussion}

We moved from the evidence that both the Eph/ephrin system and group I mGlu receptors interact with NMDA receptors and are involved in the regulation of synaptic plasticity during development and in adulthood. Group I mGlu receptors, mGlu1 and mGlu5 receptors, are both coupled to Gq-proteins, and their activation stimulates PI hydrolysis with ensuing intracellular $\mathrm{Ca}^{2+}$ release and activation of protein kinase C (De Blasi et al., 2001). We found here that ephrinB2 coimmunoprecipitates with mGlula receptors in different regions of rats at P6-7. Coimmunoprecipitation between ephrinB2 and mGlu5 receptors was mainly detected in the corpus striatum. The specificity of these data was strengthened by the lack of mGlula or mGlu5 receptors in ephrinA1 immunoprecipitates. Interestingly, ephrinB2,
mGlula, and mGlu5 receptors also coimmunoprecipitated with the NR1 subunit of NMDA receptors. This suggests that ephrinBs associate with mGlu receptors and that association with NMDA receptors is not restricted to EphB receptors (for review, see Palmer and Klein, 2003) but extends to ephrinB ligands. The latter possibility has been raised by Grunwald et al. (2004), who showed that postsynaptic ephrinB2 and NMDA receptors interact in the induction of long-term potentiation in the hippocampus. It is noteworthy that group I mGlu receptors are also involved in the regulation of hippocampal synaptic plasticity (Bortolotto et al., 1999).

Based on FRET and redistribution analysis in HEK293 cells, we conclude that a direct interaction between ephrinB2 and mGlu1 or mGlu5 receptors is unlikely to occur. However, an interaction at the $\mathrm{C}$ terminus could have been masked by the large fluorescent protein tags or, alternatively, requires additional proteins that are not present in HEK293 cells. We found that ephrinB2 coimmunoprecipitates with Homer proteins in brain tissue. These proteins interact with the C-terminus domain of mGlula or mGlu5 receptors (Brakeman et al., 1997; Xiao et al., 2000) and regulate receptor targeting (Ango et al., 2000, 2002) and coupling to other receptors, adaptors, and signaling proteins (Tu et al., 1999; Kammermeier et al., 2000). The use of a panHomer antibody revealed that ephrinB2 coimmunoprecipitated with putative Homer-1b/c but not with the shorter isoform, Homer-1a. Interestingly, only the long isoforms of Homer (such as Homer-1b and -1c) can be involved in the formation of multiprotein complexes (Xiao et al., 2000). Long isoforms of Homer mediate physical interaction between group I mGlu and NMDA receptors through additional anchoring proteins ( $\mathrm{Tu}$ et al., 1999).

We examined whether a functional interaction exists between group I mGlu receptors and ephrinB2 using three different models as follows: (1) brain slices prepared from the striatum of P6-7 rats; (2) primary cultures of rat cerebellar granule cells; and (3) 
A

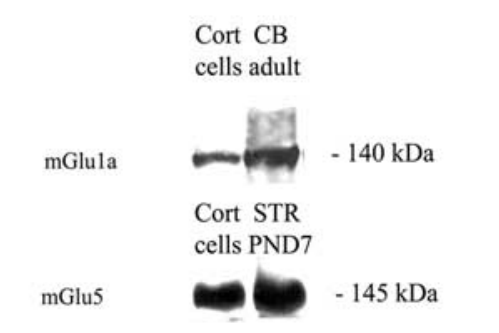

Cort STR

cells PND7

ephrinB2

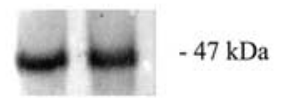

B

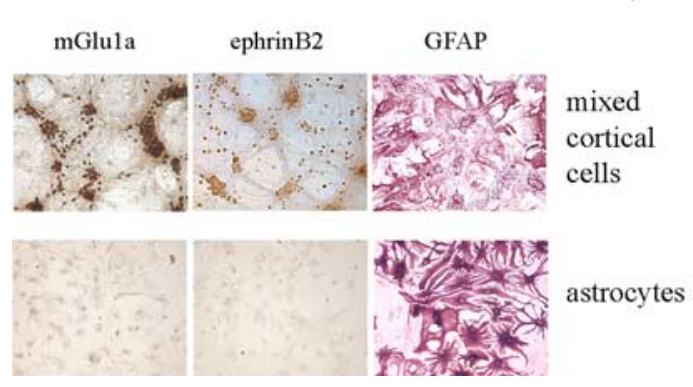

Figure 6. Clustered EphB1/Fc amplifies the enhancing effect of group I mGlu receptor agonists on NMDA toxicity in cultured cortical cells. Western blot analysis of mGlu1a receptor, mGlu5 receptor, and ephrinB2 in mixed cultures of mouse cortical cells (Cort cells) is shown in $\boldsymbol{A}$. Expression in the cerebellum (CB) and corpus striatum (STR) is also shown. Immunohistochemical analysis of mGlu1a receptors and ephrinB2 in mixed cultures of cortical cells (top) and in pure cultures of cortical astrocytes (bottom) are shown in $\boldsymbol{B}$. Astrocytes in both cultures are stained with GFAP antibodies. Potentiation of NMDA toxicity by quisqualate or DHPG in cultured cortical cells incubated in the absence or presence of clustered EphB1/Fc is shown in $\boldsymbol{B}$ and $\boldsymbol{C}$, respectively. Values are means \pm 9 determinations from three independent experiments. ${ }^{*} p<0.05$ (Student's $t$ test) compared with the corresponding values obtained in the absence of clustered EphB1/Fc.

Table 4. Clustered EphB1/Fc fails to amplify NMDA toxicity in cultured cortical cells treated with mGlu1 receptor antagonists

\begin{tabular}{lcc}
\hline & \multicolumn{2}{l}{ Percentage of NMDA toxicity } \\
\cline { 2 - 3 } & Control & Clustered EphB1/Fc $(0.5 \mu \mathrm{g} / \mathrm{ml})$ \\
\hline Basal & $96 \pm 4$ & $115 \pm 5^{*}$ \\
Quisqualate $(100 \mathrm{~nm})$ & $145 \pm 6$ & $200 \pm 8^{*}$ \\
MPEP $(3 \mu \mathrm{M})$ & $76 \pm 5$ & $75 \pm 4$ \\
MPEP $(3 \mu \mathrm{M})$ plus quisqualate $(100 \mathrm{~nm})$ & $102 \pm 5.2$ & $145 \pm 6^{*}$ \\
CPCCOEt $(10 \mu \mathrm{M})$ & $90 \pm 7$ & $94 \pm 8$ \\
CPCCOEt $(10 \mu \mathrm{M})$ plus quisqualate (100 nM) & $92 \pm 6$ & $91 \pm 6.5$ \\
LY367385 $(1 \mu \mathrm{M})$ & $74 \pm 4$ & $75 \pm 7$ \\
LY367385 $(1 \mu \mathrm{M})$ plus quisqualate $(100 \mathrm{~nm})$ & $76 \pm 5$ & $78 \pm 7.2$ \\
\hline
\end{tabular}

Values are means \pm SEM of four determinations. ${ }^{*} p<0.05$ (Student's $t$ test) versus the corresponding control values.

mixed cultures of mouse cortical cells. We focused on striatal slices because of the established role for the ephrinB2/EphB1 system in the development of the nigro-striatal pathway and in drug-induced striatal plasticity (Yue et al., 1999; Halladay et al., 2000). EphrinB2 activated by clustered EphB1/Fc increased the potency of $\mathrm{mGlu}$ receptor agonists in enhancing PI hydrolysis in striatal slices, suggesting an increased ligand affinity at mGlu receptors or an increased efficiency of receptor signaling. Potentiation was abolished by mGlu1 (but not mGlu5) receptor antagonists, indicating that activated ephrinB2 specifically amplified responses mediated by mGlul receptors. Interestingly, NMDA receptor blockade by MK-801, which did not affect the PI response by itself (Nicoletti et al., 1986a,b), inhibited the amplifying activity of activated ephrinB2. This discloses an unexpected NMDA component in the PI response to mGlu receptor agonists, which becomes unmasked after activation of ephrinB2. Although the underlying mechanism is unclear, we suggest the following models. It is possible that activated ephrinB2 relieves the $\mathrm{Mg}^{2+}$ blockade of the NMDA channel (the slice incubation buffer contained $1.2 \mathrm{mM} \mathrm{Mg}^{2+}$ ), thus allowing the activation of NMDA receptors by the endogenous glutamate. $\mathrm{Ca}^{2+}$ influx would then amplify mGlul receptor signaling by preventing receptor desensitization (Alagarsamy et al., 1999). Alternatively, activated ephrinB2 might promote a cascade of reactions by primarily facilitating mGlu1 receptors. Activation of protein kinase $\mathrm{C}$ would then relieve the $\mathrm{Mg}^{2+}$ blockade of the NMDA receptor (Chuang et al., 2000), thus allowing $\mathrm{Ca}^{2+}$ influx and a additional amplification of mGlu1 receptor signaling. These hypotheses do not exclude that other protein partners are involved. PDZ-containing regulators of G-protein signaling (RGS) proteins are likely candidates, because they are known to bind ephrinB (Lu et al., 2001) and potentially interact with both mGlula and NMDA receptors through their PDZ domain. RGS proteins accelerate the GTPase activity of the $\alpha$ subunit of the G-proteins, thus inhibiting signal transduction at G-protein-coupled receptors (Dohlman and Thorner, 1997). At least two RGS proteins (i.e., RGS2 and RGS4) inhibit mGlula receptor signaling (Saugstad et al., 1998; Kammermeier et al., 1999). The PDZ-RGS, RGS3, coimmunoprecipitated with both ephrinB2 and mGlula receptors, raising the possibility that mGlula receptor signaling is regulated by RGS3 and that activated ephrinB2 interferes with this regulation. All of these models are based on the assumption that ephrinB2, mGlu1a, and NMDA receptors act in cis on the same membrane domain, presumably at the postsynaptic site of striatal neurons, where all these proteins are predominantly found in the first week of postnatal life (Yue et al., 1999; Smith et al., 2000). This is somehow in contrast with studies showing that it is rather the EphB receptor that interacts in cis with NMDA receptors on the postsynaptic membrane (Dalva et al., 2000) but may be consistent with the recent finding by Grunwald et al. (2004) (see above).

Group I mGlu receptors might be part of a ternary complex with ephrinB2 and NMDA receptors at postsynaptic densities, thus regulating different aspects of synaptic plasticity not only in 
A

mGlu5-CFP + ephrinB2-YFP

mGlu1-CFP + ephrinB2-YFP

CFP.SERT.YFP
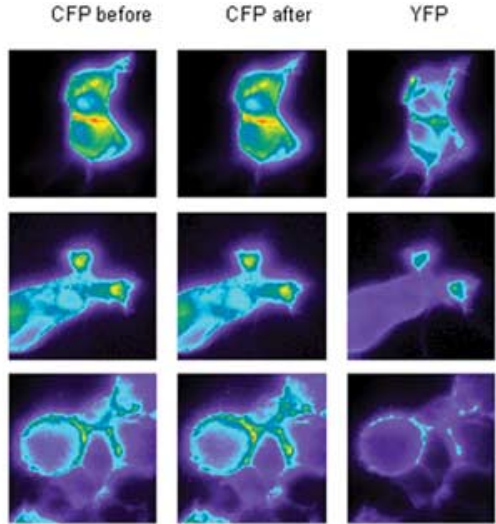

mGlu5-CFP + mGlu5-YFP

D2-CFP + mGlu5-YFP

mGlu5-CFP + ephrinB2-YFP

mGlu1-CFP + ephrinB2-YFP

CFP.SERT.YFP
B

mGlu5-CFP vs ephrinB2-YFP

mGlu5-CFP vs ephrinB2-YFP

+ EphB1-Fc

mGlu1-CFP vs ephrin B2-YFP + EphB1-Fc

mGlu5-CFP vs ephrin B2-YFP $+\mathrm{DHPG}+$ EphB1-Fc

mGlu1-CFP vs ephrin B2-YFP + DHPG + EphB1-Fc
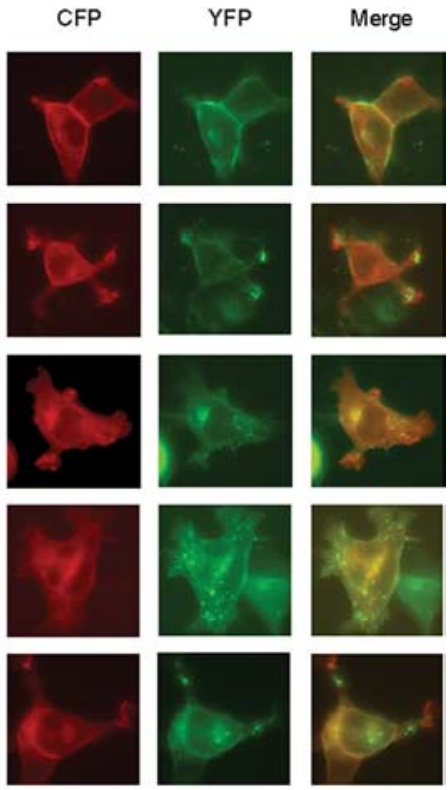

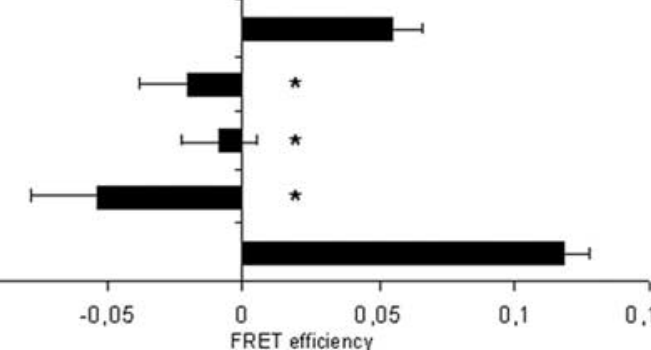

FRET efficiency

0.1

0.15

Figure 7. Lack of physical association between recombinantly expressed ephrinB2 and group I mGlu receptors. $A$, Donor photobleaching and DRAP FRET microscopy. The indicated pairs of CFPor YFP-labeled constructs were coexpressed in HEK293 cells at 1:1 ratio of donor to acceptor. A CFP-labeled $D_{2}$ dopamine receptor was used as a negative control. A double-labeled human serotonin transporter (SERT), which is known to form oligomers (Just et al., 2004), was used as a positive control. DRAP FRET microscopy experiments were performed $24 \mathrm{~h}$ after transfection. To measure DRAP, a donor (CFP) image was acquired before and after photobleaching using the YFP setting for $90 \mathrm{~s}$ (excitation, $500 \mathrm{~nm}$; dichroic mirror, $525 \mathrm{~nm}$; emission, $535 \mathrm{~nm}$ ). FRET efficiencies (mean \pm SE; calculated as described in Materials and Methods) were significantly different ( $p<0.05$, judged by one-way ANOVA followed by Tukey's multiple comparison test) from positive controls (mGlu5-CFP vs mGlu5-YFP; (FP-SERT-YFP), indicated by an asterisk. B, Clustering of YFP-tagged ephrinB2. Twenty-four hours after transfection, cells expressing both constructs were incubated at $37^{\circ} \mathrm{C}$ with EphB1-Fc preclustered with anti-human IgG according to the protocol described in Materials and Methods (in the presence or absence of DHPG; $50 \mu \mathrm{M}$ ). After 20 min, the coverslips were mounted for fluorescence microscopy, and images with CFP and YFP settings were acquired. The images are representative of three independent experiments.

the striatum but also in other brain regions. The widespread nature of this interaction is suggested by results obtained with the two additional models (i.e., cultured cerebellar granule cells and mixed cultures of mouse cortical cells). Cultured cerebellar granule cells are usually grown in medium containing $25 \mathrm{~mm} \mathrm{~K}^{+}$, a condition that mimics the excitatory drive provided by mossy fibers in the intact cerebellum. If extracellular $\mathrm{K}^{+}$concentration is $<25 \mathrm{~mm}$, cells are viable only for $4 \mathrm{~d}$ and then die by apoptosis (Gallo et al., 1987). Activated ephrinB2 potentiated glutamate or quisqualate-stimulated PI hydrolysis only under growth conditions that favored the expression of mGlu la receptors (i.e., in K25 cultures at 9 DIV) (Copani et al., 1998). Potentiation required again the activation of NMDA receptors, which here contributed to the overall response to glutamate even in the absence of clustered EphB1/Fc (Nicoletti et al., 1986c, 1987). This is not surprising, because glutamate may activate AMPA or kainate receptors expressed by mature granule cells (Condorelli et al., 1993), thus depolarizing neuronal membranes and relieving the $\mathrm{Mg}^{2+}$ blockade of the NMDA channel.

Mixed cultures of mouse cortical cells have been widely used for the characterization of how group I mGlu receptors modulate excitotoxic neuronal death. mGlu1/5 receptor agonists may either facilitate or reduce NMDA toxicity depending on the functional state of $\mathrm{mGlu}$ receptors (i.e., naive vs preactivated) and on the presence of astrocytes (Bruno et al., 1995, 2001; Buisson and Choi, 1995; Nicoletti et al., 1999). In contrast, mGlu1 or mGlu5 receptor antagonists are consistently neuroprotective (for review, see Bruno et al., 2001). Using an experimental protocol in which
mGlu1/5 receptor agonists enhance NMDA toxicity (Bruno et al., 1995), we found that activated ephrinB2 further amplified the action of these drugs and that amplification was abrogated by mGlu1 receptor antagonists. Both ephrinB2 and mGlula receptors were expressed by neurons and not by astrocytes in cortical cultures, although the presence of ephrinB in astrocytes has been reported previously (Conover et al., 2000; Bundesen et al., 2003). Our data raise the possibility that ephrins are involved in processes of neurodegeneration/neuroprotection.

In conclusion, we have provided evidence for a novel form of interaction among ephrinB2, mGlu1a receptors, and NMDA receptors in the developing brain. Although the precise subcellular localization of this interaction is unknown, we suggest that all of these proteins act in cis in the same membrane domain. Interestingly, studies on striatal slices disclose an NMDA component in the PI response to mGlu receptor agonists that was not recognized in previous studies. Whether activated ephrinB2 primarily facilitates NMDA receptor activation (which in turn potentiates mGlula receptor signaling) or directly amplifies mGlula responses (thus promoting a vicious circle leading to a secondary activation of NMDA receptors and then to a further amplification of mGlula signaling) remains to be determined. Whatever the mechanism(s), our observations introduce a new partner (i.e., the mGlula receptor) in the ephrinB/EphB-NMDA receptor network. This might have important implications in the regulation of developmental plasticity, associative learning, and even in the regulation of pain threshold, which involves the ephrin/Eph system (Battaglia et al., 2003) as well as group I mGlu 
receptors (Neugebauer, 2002; Varney and Gereau, 2002). It will be interesting to examine whether strategies aimed at preventing ephrinB2 activation will reduce mGlula receptor signaling and disrupt the physiological interplay between group I mGlu receptors and NMDA receptors. This might be relevant to the experimental treatment of neurodegenerative disorders and chronic pain.

\section{References}

Alagarsamy S, Marino MJ, Rouse ST, Gereau IV RW, Heinemann SF, Conn PJ (1999) Activation of NMDA receptors reverses desensitization of mGluR5 in native and recombinant systems. Nat Neurosci 2:234-240.

Ango F, Pin JP, Tu JC, Xiao B, Worley PF, Bockaert J, Fagni L (2000) Dendritic and axonal targeting of type 5 metabotropic glutamate receptor is regulated by homerl proteins and neuronal excitation. J Neurosci 20:8710-8716.

Ango F, Robbe D, Tu JC, Xiao B, Worley PF, Pin JP, Bockaert J, Fagni L (2002) Homer-dependent cell surface expression of metabotropic glutamate receptor type 5 in neurons. Mol Cell Neurosci 20:323-329.

Aniksztejn L, Sciancalepore M, Ben Ari Y, Cherubini E (1995) Persistent current oscillations produced by activation of metabotropic glutamate receptors in immature rat CA3 hippocampal neurons. J Neurophysiol 73:1422-1429.

Awad H, Hubert GW, Smith Y, Levey AI, Conn PJ (2000) Activation of metabotropic glutamate receptor 5 has direct excitatory effects and potentiates NMDA receptor currents in neurons of the subthalamic nucleus. J Neurosci 20:7871-7879.

Battaglia AA, Sehayek K, Grist J, McMahon SB, Gavazzi I (2003) EphB receptors and ephrin-B ligands regulate spinal sensory connectivity and modulate pain processing. Nat Neurosci 6:339-340.

Battaglia G, Bruno V, Pisani A, Centonze D, Catania MV, Calabresi P, Nicoletti F (2001) Selective blockade of type-1 metabotropic glutamate receptors induces neuroprotection by enhancing GABAergic transmission. Mol Cell Neurosci 17:1071-1083

Bortolotto ZA, Fitzjohn SM, Collingridge GL (1999) Roles of metabotropic glutamate receptors in LTP and LTD in the hippocampus. Curr Opin Neurobiol 9:299-304.

Brakeman PR, Lanahan AA, O’Brien R, Roche K, Barnes CA, Huganir RL, Worley PF (1997) Homer: a protein that selectively binds metabotropic glutamate receptors. Nature 386:284-288.

Bruckner K, Pasquale EB, Klein R (1997) Tyrosine phosphorylation of transmembrane ligands for Eph receptors. Science 275:1640-1643.

Bruckner K, Pablo Labrador J, Scheiffele P, Herb A, Seeburg PH, Klein R (1999) EphrinB ligands recruit GRIP family PDZ adaptor proteins into raft membrane microdomains. Neuron 22:511-524.

Bruno V, Copani A, Knopfel T, Kuhn R, Casabona G, Dell'Albani P, Condorelli DF, Nicoletti F (1995) Activation of metabotropic glutamate receptors coupled to inositol phospholipid hydrolysis amplifies NMDAinduced neuronal degeneration in cultured cortical cells. Neuropharmacology 34:1089-1098.

Bruno V, Ksiazek I, Battaglia G, Lukic S, Leonhardt T, Sauer D, Gasparini F, Kuhn R, Nicoletti F, Flor PJ (2000) Selective blockade of metabotropic glutamate receptor subtype 5 is neuroprotective. Neuropharmacology 39:2223-2230.

Bruno V, Battaglia G, Copani A, Cespedes VM, Galindo MF, Cena V, Sanchez-Prieto J, Gasparini F, Kuhn R, Flor PJ, Nicoletti F (2001) An activity-dependent switch from facilitation to inhibition in the control of excitotoxicity by group I metabotropic glutamate receptors. Eur J Neurosci 13:1469-1478.

Buchert M, Schneider S, Meskenaite V, Adams MT, Canaani E, Baechi T, Moelling K, Hovens CM (1999) The junction-associated protein AF-6 interacts and clusters with specific Eph receptor tyrosine kinases at specialized sites of cell-cell contact in the brain. J Cell Biol 144:361-371.

Buisson A, Choi DW (1995) The inhibitory mGluR agonist S-4-carboxy-3hydroxy-phenylglycine selectively attenuates NMDA neurotoxicity and oxygen-glucose deprivation-induced neuronal death. Neuropharmacology 34:1081-1087.

Bundesen LQ, Scheel TA, Bregman BS, Kromer LF (2003) Ephrin-B2 and EphB2 regulation of astrocytes-meningeal fibroblast interactions in response to spinal cord lesions in adult rats. J Neurosci 23:7789-7800.

Casabona G, Knopfel T, Kuhn R, Gasparini F, Baumann P, Sortino MA,
Copani A, Nicoletti F (1997) Expression and coupling to polyphosphoinositide hydrolysis of group I metabotropic glutamate receptors in early postnatal and adult rat brain. Eur J Neurosci 9:12-17.

Chuang SC, Bianchi R, Wong RK (2000) Group I mGluR activation turns on a voltage-gated inward current in hippocampal pyramidal cells. J Neurophysiol 83:2844-2853.

Condorelli DF, Dell'Albani P, Aronica E, Genazzani AA, Casabona G, Corsaro M, Balazs R, Nicoletti F (1993) Growth conditions differentially regulate the expression of alpha-amino-3-hydroxy-5-methylisoxazole-4propionate (AMPA) receptor subunits in cultured neurons. J Neurochem 61:2133-2139.

Conover JC, Doetsch F, Garcia-Verdugo JM, Gale NW, Yancopoulos GD, Alvarez-Buylla A (2000) Disruption of Eph/ephrin signaling affects migration and proliferation in the adult subventricular zone. Nat Neurosci 3:1091-1097.

Copani A, Casabona G, Bruno V, Caruso A, Condorelli DF, Messina A, Di Giorgi Gerevini V, Pin JP, Kuhn R, Knopfel T, Nicoletti F (1998) The metabotropic glutamate receptor mGlu5 controls the onset of developmental apoptosis in cultured cerebellar neurons. Eur J Neurosci 10:2173-2184.

Cowan CA, Henkemeyer M (2001) The SH2/SH3 adaptor Grb4 transduces B-ephrin reverse signals. Nature 413:174-179.

Dalva MB, Takasu MA, Lin MZ, Shamah SM, Hu L, Gale NW, Greenberg ME (2000) EphB receptors interact with NMDA receptors and regulate excitatory synapse formation. Cell 103:945-956.

De Blasi A, Conn PJ, Pin J, Nicoletti F (2001) Molecular determinants of metabotropic glutamate receptor signaling. Trends Pharmacol Sci 22:114-120.

Dohlman HG, Thorner J (1997) RGS proteins and signaling by heterotrimeric $G$ proteins. J Biol Chem 272:3871-3874.

Dudek SM, Bear MF (1989) A biochemical correlate of the critical period for synaptic modification in the visual cortex. Science 246:673-675.

Gallo V, Kingsbury A, Balazs R, Jorgensen OS (1987) The role of depolarization in the survival and differentiation of cerebellar granule cells in culture. J Neurosci 7:2203-2213.

Genazzani AA, L'Episcopo MR, Casabona G, Shinozaki H, Nicoletti F (1994) ( $\left.2 S, 1^{\prime} \mathrm{R}, 2^{\prime} \mathrm{R}, 3^{\prime} \mathrm{R}\right)$-2-(2,3-dicarboxycyclopropyl) glycine positively modulates metabotropic glutamate receptors coupled to polyphosphoinositide hydrolysis in rat hippocampal slices. Brain Res 659:10-16.

Grunwald IC, Korte M, Adelmann G, Plueck A, Kullander K, Adams RH, Frotscher M, Bonhoeffer T, Klein R (2004) Hippocampal plasticity requires postsynaptic ephrinBs. Nat Neurosci 7:33-40.

Halladay AK, Yue Y, Michna L, Widmer DA, Wagner GC, Zhou R (2000) Regulation of EphB1 expression by dopamine signaling. Brain Res Mol Brain Res 85:171-178.

Heidinger V, Manzerra P, Wang XQ, Strasser U, Yu SP, Choi DW, Behrens MM (2002) Metabotropic glutamate receptor 1-induced upregulation of NMDA receptor current: mediation through the Pyk2/Src-family kinase pathway in cortical neurons. J Neurosci 22:5452-5461.

Himanen JP, Chumley MJ, Lackmann M, Li C, Barton WA, Jeffrey PD, Vearing C, Geleick D, Feldheim DA, Boyd AW, Henkemeyer M, Nikolov DB (2004) Repelling class discrimination: ephrin-A5 binds to and activates EphB2 receptor signalling. Nat Neurosci 7:501-509.

Holland SJ, Gale NW, Mbamalu G, Yancopoulos GD, Henkemeyer M, Pawson T (1996) Bidirectional signalling through the EPH-family receptor Nuk and its transmembrane ligand. Nature 383:722-725.

Jia Z, Lu Y, Henderson J, Taverna F, Romano C, Abramow-Newerly W, Wojtowicz JM, Roder J (1998) Selective abolition of the NMDA component of long-term potentiation in mice lacking mGluR5. Learn Mem 5:331-343.

Just H, Sitte HH, Schmid JA, Freissmuth M, Kudlacek O (2004) Identification of an additional interaction domain in transmembrane domains 11 and 12 that supports oligomer formation in the human serotonin transporter. J Biol Chem 279:6650-6657.

Kammermeier PJ, Xiao B, Tu JC, Worley PF, Ikeda SR (2000) Homer proteins regulate coupling of group I metabotropic glutamate receptors to N-type calcium and M-type potassium channels. J Neurosci 20:7238-7245.

Kotecha SA, MacDonald JF (2003) Signalling molecules and receptor transduction cascades that regulate NMDA receptor-mediated synaptic transmission. Int Rev Neurobiol 54:51-106. 
Kullander K, Klein R (2002) Mechanisms and functions of Eph and ephrin signalling. Nat Rev Mol Cell Biol 3:475-486.

Lan JY, Skeberdis VA, Jover T, Zheng X, Bennett MV, Zukin RS (2001) Activation of metabotropic glutamate receptor 1 accelerates NMDA receptor trafficking. J Neurosci 21:6058-6068.

Lu Q, Sun EE, Klein RS, Flanagan JG (2001) Ephrin-B reverse signalling is mediated by a novel PDZ-RGS protein and selectively inhibits G proteincoupled chemoattraction. Cell 105:69-79.

Minakami R, Iida K, Hirakawa N, Sugiyama H (1995) The expression of two splice variants of metabotropic glutamate receptor subtype 5 in the rat brain and neuronal cells during development. J Neurochem 65:1536-1542.

Miyawaki A, Tsien RY (2000) Monitoring protein conformations and interactions by fluorescence resonance energy transfer between mutants of green fluorescent protein. Methods Enzymol 327:472-500.

Neugebauer V (2002) Metabotropic glutamate receptors important modulators of nociception and pain behavior. Pain 98:1-8.

Nicoletti F, Iadarola MJ, Wroblewski JT, Costa E (1986a) Excitatory amino acid recognition sites coupled with inositol phospholipid metabolism: developmental changes and interaction with alpha 1-adrenoceptors. Proc Natl Acad Sci USA 83:1931-1935.

Nicoletti F, Meek JL, Iadarola MJ, Chuang DM, Roth BL, Costa E (1986b) Coupling of inositol phospholipid metabolism with excitatory amino acid recognition sites in rat hippocampus. J Neurochem 46:40-46.

Nicoletti F, Wroblewski JT, Novelli A, Alho H, Guidotti A, Costa E (1986c) The activation of inositol phospholipid metabolism as a signaltransducing system for excitatory amino acids in primary cultures of cerebellar granule cells. J Neurosci 6:1905-1911.

Nicoletti F, Wroblewski JT, Costa E (1987) Magnesium ions inhibit the stimulation of inositol phospholipid hydrolysis by endogenous excitatory amino acids in primary cultures of cerebellar granule cells. J Neurochem 48:967-973.

Nicoletti F, Bruno V, Catania MV, Battaglia G, Copani A, Barbagallo G, Cena V, Sanchez-Prieto J, Spano PF, Pizzi M (1999) Group-I metabotropic glutamate receptors: hypotheses to explain their dual role in neurotoxicity and neuroprotection. Neuropharmacology 38:1477-1484.

Palmer A, Klein R (2003) Multiple roles of ephrins in morphogenesis, neuronal networking, and brain function. Genes Dev 17:1429-1450.

Palmer A, Zimmer M, Erdmann KS, Eulenburg V, Porthin A, Heumann R, Deutsch U, Klein R (2002) EphrinB phosphorylation and reverse signalling: regulation by Src kinases and PTP-BL phosphatase. Mol Cell 9:725-737.

Parker M, Roberts R, Enriquez M, Zhao X, Takahashi T, Pat Cerretti D, Daniel T, Chen J (2004) Reverse endocytosis of transmembrane ephrin-B ligands via a clathrin-mediated pathway. Biochem Biophys Res Commun 323:17-23.

Pasquale EB (2004) Eph-ephrin promiscuity is now crystal clear. Nat Neurosci 7:417-418.

Pisani A, Gubellini P, Bonsi P, Conquet F, Picconi B, Centonze D, Bernardi G, Calabresi P (2001) Metabotropic glutamate receptor 5 mediates the potentiation of $N$-methyl-D-aspartate responses in medium spiny striatal neurons. Neuroscience 106:579-587.

Romano C, van den Pol AN, O’Malley KL (1996) Enhanced early developmental expression of the metabotropic glutamate receptor mGluR5 in rat brain: protein, mRNA splice variants, and regional distribution. J Comp Neurol 367:403-412.
Rose K, Goldberg MP, Choi DW (1992) Cytotoxicity in murine neocortical cell culture. In: Methods in toxicology, Vol 1, In vitro biological systems (Tyson CA, Frazier JM, eds), pp 46-60. San Diego: Academic.

Saugstad JA, Marino MJ, Folk JA, Hepler JR, Conn PJ (1998) RGS4 inhibits signalling by group I metabotropic glutamate receptors. J Neurosci 18:905-913.

Schmid JA, Scholze P, Kudlacek O, Freissmuth M, Singer EA, Sitte HH (2001) Oligomerization of the human serotonin transporter and of the rat GABA transporter 1 visualized by fluorescence resonance energy transfer microscopy in living cells. J Biol Chem 276:3805-3810.

Schoepp DD, Johnson BG (1989) Inhibition of excitatory amino acidstimulated phosphoinositide hydrolysis in the neonatal rat hippocampus by 2-amino-3-phosphonopropionate. J Neurochem 53:1865-1870.

Schoepp DD, Salhoff CR, Wright RA, Johnson BG, Burnett JP, Mayne NG, Belagaje R, Wu S, Monn JA (1996) The novel metabotropic glutamate receptor agonist 2R,4R-APDC potentiates stimulation of phosphoinositide hydrolysis in the rat hippocampus by 3,5-dihydroxyphenylglycine: evidence for a synergistic interaction between group 1 and group 2 receptors. Neuropharmacology 35:1661-1672.

Schoepp DD, Jane DE, Monn JA (1999) Pharmacological agents acting at subtypes of metabotropic glutamate receptors. Neuropharmacology 38:1431-1476.

Skeberdis VA, Lan J, Opitz T, Zheng X, Bennett MV, Zukin RS (2001) mGluR1-mediated potentiation of NMDA receptors involves a rise in intracellular calcium and activation of protein kinase C. Neuropharmacology 40:856-865.

Smith Y, Charara A, Hanson JE, Paquet M, Levey AI (2000) $\mathrm{GABA}_{\mathrm{B}}$ and group I metabotropic glutamate receptors in the striatopallidal complex in primates. J Anat 196:555-576.

Su Z, Xu P, Ni F (2004) Single phosphorylation of Tyr304 in the cytoplasmic tail of ephrin B2 confers high-affinity and bifunctional binding to both the SH2 domain of Grb4 and the PDZ domain of the PDZ-RGS3 protein. Eur J Biochem 271:1725-1736.

Takasu MA, Dalva MB, Zigmond RE, Greenberg ME (2002) Modulation of NMDA receptor-dependent calcium influx and gene expression through EphB receptors. Science 295:491-495.

Torres R, Firestein BL, Dong H, Staudinger J, Olson EN, Huganir RL, Bredt DS, Gale NW, Yancopoulos GD (1998) PDZ proteins bind, cluster, and synaptically colocalize with Eph receptors and their ephrin ligands. Neuron 21:1453-1463.

Tu JC, Xiao B, Naisbitt S, Yuan JP, Petralia RS, Brakeman P, Doan A, Aakalu VK, Lanahan AA, Sheng M, Worley PF (1999) Coupling of mGluR/ Homer and PSD-95 complexes by the Shank family of postsynaptic density proteins. Neuron 23:583-592.

Xiao B, Tu JC, Worley PF (2000) Homer: a link between neural activity and glutamate receptor function. Curr Opin Neurobiol 10:370-374.

Yue Y, Widmer DA, Halladay AK, Cerretti DP, Wagner GC, Dreyer JL, Zhou $\mathrm{R}$ (1999) Specification of distinct dopaminergic neural pathways: roles of the Eph family receptor EphB1 and ligand ephrin-B2. J Neurosci 19:2090-2101.

Varney MA, Gereau IV RW (2002) Metabotropic glutamate receptor involvement in models of acute and persistent pain: prospects for the development of novel analgesics. Curr Drug Targets CNS Neurol Disord 1:283-296. 